Teologia i Moralność, Volumen 13(2018), numer 2(24)

doi: 10.14746/tim.2018.24.2.8

ORCID: 0000-0002-1421-5411

MIKOŁAJ GĘBKA

Uniwersytet im. Adama Mickiewicza w Poznaniu

Wydział Teologiczny

\title{
(Nie)dopuszczalne ograniczanie liczby potomstwa? Refleksja o aborcji w świadomości społecznej Polaków (na podstawie badań opinii publicznej)
}

Pół wieku temu została ogłoszona - szeroko do dziś komentowana - encyklika Pawła VI Humanae vitae ${ }^{1}$. Można odnaleźć w niej bogactwo zagadnień dotyczących miłości małżeńskiej (a szczególnie jej wymiaru fizycznego), która nierozerwalnie wiąże się z prokreacją (przynajmniej potencjalną). $\mathrm{Na}$ marginesie trzeba zauważyć, że obecnie owa nierozerwalność wcale nie jest tak oczywista, bardzo często bowiem pokazuje się rozerwanie związku seks prokreacja - czy mówiąc językiem encykliki - aspektów jedności i płodności. Widać to chociażby w socjologicznych analizach funkcji rodziny, w przypadku których np. Zbigniew Tyszka (por. np. Tyszka 2001) w ramach grupy funkcji biopsychicznych wydzielił jako odrębne funkcje: seksualną i prokreacyjną; z kolei Franciszek Adamski (por. Adamski 2002) wspominał z jednej strony o funkcji prokreacyjnej (biologicznej) jako jednej z grupy funkcji instytucjonalnych, a z drugiej o funkcji małżeńskiej, związanej z zaspokajaniem potrzeb intymnych małżonków, a będącej częścią grupy funkcji osobowych. Oczywiście aktywność płciowa małżonków może w jednym momencie być realizacją obu funkcji, jednakże wcale tak być nie musi. Co więcej, w obliczu rozwoju metod antykoncepcji oraz sztucznego zapłodnienia ów związek jest obecnie coraz silniej rozrywany.

Wśród przywołanego bogactwa zagadnień w Humanae vitae są również poruszane kwestie trudne, jak chociażby różne moralnie niedopuszczalne for-

${ }^{1}$ Por. Paweł VI, Encyklika Humanae vitae, Opoka.org.pl, 05.07.1999, https://opoka.org.pl/ biblioteka/W/WP/pawel_vi/encykliki/humane.html [dostęp: 28.03.2018]. 
my ograniczania liczby potomstwa. Paweł VI wskazywał tu „,bezpośrednie naruszanie rozpoczętego już procesu życia, a zwłaszcza bezpośrednie przerywanie ciąży, choćby dokonywane ze względów leczniczych"2, jak również „,bezpośrednie obezpłodnienie czy to stałe, czy czasowe, zarówno mężczyzny, jak i kobiety"3 czy wreszcie ,wszelkie działanie, które - bądź to w przewidywaniu zbliżenia małżeńskiego, bądź podczas jego spełniania, czy w rozwoju jego naturalnych skutków - miałoby za cel uniemożliwienie poczęcia lub prowadziłoby do tego"4 - a zatem mowa jest tu o usunięciu ciąży (aborcji ${ }^{5}$ ), sterylizacji, antykoncepcji etc. $\mathrm{Z}$ wymienionych form przedmiotem analizy w niniejszym artykule jest aborcja.

Odnosząc się do problemu przywołanego w tytule - a więc kwestii uznania aborcji za dopuszczalną bądź niedopuszczalną formę ograniczania liczby potomstwa - można zauważyć, że oficjalnie aborcja nie jest traktowana jako element programu planowania rodziny, co znalazło swój wyraz w przyjętych jednomyślnie ustaleniach kairskiej konferencji ludnościowej z roku 1994 (por. Holzer 2006, s. 21-36; Goldberg 2011). Jednak trwające od jakiegoś czasu dyskusje w kontekście modyfikacji komentarza do artykułu 6 Międzynarodowego Paktu Praw Obywatelskich i Politycznych (mówiącego o prawie każdej istoty ludzkiej do życia) ${ }^{6}$ pokazują, że sytuacja nie jest już tak oczywista, gdyż

\footnotetext{
${ }^{2}$ Tamże, pkt 14 .

${ }^{3}$ Tamże.

${ }^{4}$ Tamże.
}

${ }^{5}$ Kiedy mowa jest o przerwaniu/usunięciu ciąży, używane są różne określenia, mające nieraz bardzo silne zabarwienie emocjonalne i/lub ideologiczne (np. spędzanie płodu, sztuczne poronienie, łyżeczkowanie, wywoływanie miesiączki, skrobanka, aborcja, zabicie dziecka poczętego/nienarodzonego). W dalszej części niniejszego artykułu będzie używane określenie aborcja, co wynika z faktu, iż to sformułowanie jest na ogół stosowane w badaniach opinii publicznej.

${ }^{6}$ Por. np. Globalna koalicja zwalcza wysitki ONZ zmierzające do ogtoszenia aborcji „prawem człowieka", w: Polityka Polska, 23.10.2017, http://politykapolska.eu/2017/10/23/globalna-koalicj a-zwalcza-wysilki-onz-zmierzajace-ogloszenia-aborcji-prawem-czlowieka/ [dostęp: 20.02.2018]; Polska chce usunięcia zapisów w dokumentach ONZ. Chodzi o dostęp do aborcji i karanie kobiet, w: Gazeta.pl, 12.10.2017, http://wiadomosci.gazeta.pl/wiadomosci/7,114871,22506045,polska-chce -usuniecia-zapisow-w-dokumentach-onz-chodzi-o-dostep.html [dostęp: 20.02.2018]; Wiceszef Msz: ONZ nie powinna angażować się $w$ promowanie aborcji na świecie, www.tvp.info, 13.10.2017, https://www.tvp.info/34386990/wiceszef-msz-onz-nie-powinna-angazowac-sie-w-promowanieaborcji-na-swiecie [dostęp: 20.02.2018]; Ordo Iuris odniosto się do uwag Komitetu Praw Człowieka dotyczacych dostepu do aborcji w Polsce, www.rp.pl, 30.01.2018, http://www.rp.pl/Zdrowie/3 01309957-Reakcja-Ordo-Iuris-na-uwagi-Komitetu-Praw-Czlowieka-dotyczace-dostepu-do-aborcjiw-Polsce.html [dostępu: 20.02.2018]; ONZ promuje aborcje jako... prawo człowieka, w: Fronda.pl, http://www.fronda.pl/a/onz-promuje-aborcje-jako-prawo-czlowieka,100748.html [dostęp: 25.03.2018]; Komitet praw człowieka o aborcji, w: Federacja na rzecz Kobiet i Planowania Rodziny, 13.11.2017, http://federa.org.pl/komitet-praw-czlowieka-o-aborcji/ [dostęp: 25.02.2018]; ONZ twierdzi, że aborcja jest jedna z metod planowania rodziny, w: Serwis informacyjny Fundacji „Jeden z nas", 21.04.2017, https://jedenznas.pl/onz-twierdzi-ze-aborcja-jedna-metod-planowania-rodziny/ [dostęp: 20.02.2018]. 
proponowana interpretacja wyżej wymienionego artykułu miałaby - zdaniem niektórych komentatorów - odmawiać prawa do życia dzieciom w okresie prenatalnym oraz osobom śmiertelnie chorym ${ }^{7}$. Można znaleźć również opinie, że wbrew ustaleniom z Kairu, aborcja bywa wymieniana wśród narzędzi planowania rodziny (wprawdzie w konkretnych przypadkach zagrożenia [np. wirusem Zika], ale jednak) ${ }^{8}$, a Światowa Organizacja Zdrowia (WHO) w swoich wskazówkach ${ }^{9}$ dotyczących aborcji sprzeciwia się ograniczeniom w przeprowadzaniu tego zabiegu, promując go bez względu na uregulowania prawne poszczególnych państw ${ }^{10}$.

W kontekście traktowania aborcji jako narzędzia służącego planowaniu rodziny nie można nie wspomnieć chińskiej polityki jednego dziecka (wprowadzonej w życie w roku 1979 i funkcjonującej do połowy obecnej dekady), która przez nieco ponad trzydzieści lat swego funkcjonowania mogła kosztować życie nawet $350 \mathrm{mln}$ osób ${ }^{11}$, czy problemu selektywnych aborcji, wykonywanych często nielegalnie (jak np. w Indiach w przypadku dziewczynek ${ }^{12}$ ).

Kwestię (nie)dopuszczalności aborcji w kontekście planowania rodziny można analizować nie tylko pod kątem uregulowań prawnych, deklaracji politycznych czy faktycznie podejmowanych działań - ważnym obszarem refleksji jest stanowisko opinii publicznej, tym bardziej że opinia publiczna oraz wspomniane uregulowania, deklaracje czy działania są systemem naczyń połączonych, nawzajem na siebie oddziałujących. Dlatego w dalszej części artykułu zostanie podjęta próba refleksji nad stosunkiem Polaków do aborcji i jej dopuszczalności uchwyconym w badaniach opinii społecznej. Jednakże

${ }^{7}$ Por. np. Globalna koalicja..., dz. cyt., S. Gennarini, UN pushes for international law to make abortion a human right, w: LIFESITE, 21.09.2017, https://www.lifesitenews.com/opinion/ un-pushes-for-international-law-to-make-abortion-a-human-right [dostęp: 25.03.2018]; US refuses to back UN on abortion access in human rights resolution, „The Guardian” 22.06.2017, https:// www.theguardian.com/world/2017/jun/22/women-abortion-un-human-rights-resolution-us-refuses [dostęp: 25.03.2018].

${ }^{8}$ Por. np. S. Gennarini, UN Says Women Who Want to „Avoid Pregnancy” Should Use Abortion as Family Palnning, w: LifeNews.com, 20.04.2017, http://www.lifenews.com/2017/04/20/un-sayswomen-who-want-to-avoid-pregnancy-should-use-abortion-as-family-planning/ [dostęp: 25.03.2018].

${ }^{9}$ Safe abortion: technical and Policy guidance for health systems, Wyd. 2, WHO, 2012, ISBN 9789241548434,http://apps.who.int/iris/bitstream/handle/10665/70914/9789241548434_eng.pdf?se quence=1 [dostęp: 20.03.2018].

${ }^{10}$ S. Yoshihara, R. Oas, Eleven Problems with the 2012 WHO Technical Guidance on Abortion, w: C-Fam, s. 5-7, 07.11.2012, https://c-fam.org/wp-content/uploads/11-PROBS-WITH-WHO6.pdf [dostęp: 25.03.2018].

${ }_{11}$ Por. B. Góralczyk, [Chiny] Koniec chińskiego snu, „Kultura Liberalna” nr 357(45/2015), 12.11.2015, https://kulturaliberalna.pl/2015/11/12/chiny-goralczyk-wyzwania-demografia [dostęp: 25.03.2018].

${ }^{12}$ Por. Indie - 63 miliony dziewczynek zginęlo $w$ wyniku selektywnej aborcji, w: Serwis informacyjny Fundacji „Jeden z nas”, 09.02.2018, https://jedenznas.pl/indie-63-miliony-dziewczynekzginelo-wyniku-selektywnej-aborcji/ [dostęp: 25.03.2018]. 
ze względu na wspomniane wzajemne oddziaływania warto najpierw krótko zarysować kontekst funkcjonowania zjawiska aborcji i sporów o nią w Polsce od czasów II RP.

\section{Kwestia aborcji w Polsce - ogólny kontekst}

Prawodawstwo w II Rzeczypospolitej z założenia chroniło życie poczęte kodeks karny z roku $1932^{13}$ zasadniczo penalizował aborcję, choć istniały dwa wyjątki: (1) ścisłe wskazania medyczne (zdrowie kobiety) oraz (2) ciąża będąca skutkiem współżycia, które mogło być zakwalifikowane jako: (a) gwałt, (b) wynik groźby bezprawnej czy podstępu, (c) kazirodztwo, (d) współżycie $\mathrm{z}$ nieletnią poniżej 15 roku życia lub osobą pozbawioną (zupełnie lub częściowo) zdolności do rozpoznawania znaczenia czynu lub kierowania postępowaniem, czy wreszcie jako (e) wykorzystanie stosunku zależności lub krytycznego położenia. Zakres przesłanek był zatem węższy niż w regulacjach z roku 1993 (por. Ustawa z dnia 7 stycznia 1993, nr 17, poz. 78) (brak przesłanki dotyczącej wad/chorób płodu [tzw. przesłanka „eugeniczna”]; wyraźnie sprecyzowane czyny niedozwolone).

Władze okupacyjne rozporządzeniem z dnia 9 marca 1943 roku wprowadziły nieograniczoną dopuszczalność aborcji dla Polek, jednakże wyłącznie w przypadku polskich dzieci - za zabicie nienarodzonego dziecka niemieckiego groziły kary (z karą śmierci włącznie). Po zakończeniu okupacji przywrócone zostały uregulowania $\mathrm{z}$ okresu międzywojennego ${ }^{14}$.

Zasadnicza zmiana nastąpiła w latach pięćdziesiątych XX wieku, kiedy weszła w życie Ustawa o warunkach dopuszczalności przerywania ciąży, która obowiązywała niemal 40 lat. Oficjalnie nie wprowadziła aborcji „na żądanie”, formułując tylko określone przesłanki: (1) wskazania lekarskie, (2) uzasadnione podejrzenie, że ciąża jest wynikiem przestępstwa, (3) trudne warunki życiowe kobiety ciężarnej (por. Ustawa z dnia 27 kwietnia 1956 r., nr 12, poz. 61, art. 1 par. 1). Ostatnia z wymienionych przesłanek dawała jednak szerokie pole manewru.

Kwestia aborcji na przestrzeni trzech ostatnich dekad dość regularnie powracała w przestrzeni politycznej, społecznej i medialnej. Pierwsze, nieskuteczne próby wprowadzenia prawnej ochrony dziecka poczętego podejmowano jeszcze przed rokiem 1993. Dopiero w tym roku została uchwalona

${ }^{13}$ Por. J. Makarewicz, Kodeks karny z komentarzem, wyd. 3, Lwów, Wydawnictwo Zakładu Narodowego Imienia Ossolińskich, 1932, http://www.wbc.poznan.pl/dlibra/doccontent?id=77578\&di rids=1 [dostęp: 30.01.2018] (art. 203-206, 231-233).

${ }^{14}$ Por. A. Zięba, Historia legalizacji aborcji w Europie $i$ w Polsce, w: Sanktuarium św. Józefa w Kaliszu, http://www.swietyjozef.kalisz.pl/OtoczmyTroskaZycie/13.html [dostęp: 25.01.2018]. 
obowiązująca do teraz ${ }^{15}$ Ustawa o planowaniu rodziny, ochronie płodu ludzkiego $i$ warunkach dopuszczalności przerywania ciąży (por. Ustawa z dnia 7 stycznia 1993, art. 4a, par. 1), wprowadzająca trzy przesłanki pozwalające na aborcję: (1) zagrożenie życia lub zdrowia kobiety ciężarnej, (2) duże prawdopodobieństwo ciężkiego i nieodwracalnego upośledzenia płodu lub zagrażającej jego życiu nieuleczalnej choroby, (3) uzasadnione podejrzenie, że ciąża jest wynikiem czynu zabronionego. W roku 1996 nowelizacja wyżej wymienionej ustawy wprowadziła czwartą przesłankę - ciężkie warunki życiowe/ /trudną sytuację osobistą, która jednak w roku 1997 przestała obowiązywać w wyniku orzeczenia Trybunału Konstytucyjnego o jej niekonstytucyjności ${ }^{16}$. Zdarzeniom tym towarzyszyły zakrojone na szeroką skalę dyskusje i spory dotyczące aborcji.

W pierwszej dekadzie XXI wieku kwestia aborcji była nadal obecna w przestrzeni publicznej chociażby za sprawą ciągnącej się przez kilka lat i medialnie mocno nagłośnionej sprawy kobiety, której zdrowie miało ucierpieć w wyniku odmowy aborcji (łącznie z wyrokiem Europejskiego Trybunału Praw Człowieka ${ }^{17}$ ), wizyty pływającej kliniki aborcyjnej Langenort organizacji Women on Waves czy nieudanej próby wpisania ochrony życia do konstytucji na przełomie lat 2006/2007.

W obecnej dekadzie można zauważyć zwiększenie liczby inicjatyw ustawodawczych, dążących bądź do całkowitego zakazu aborcji $(2011,2016)$ lub przynajmniej eliminacji przesłanki „eugenicznej” (2013, 2017), bądź wprost przeciwnie - do liberalizacji warunków przerywania ciąży $(2016,2017)$. Głośnym echem odbiły się również: sprawa wprowadzenia do obrotu na rynku farmaceutycznym tzw. ,antykoncepcji awaryjnej” (2015), protesty przeciw inicjatywom zaostrzającym prawo dotyczące aborcji $(2016,2017,2018)$ czy wreszcie odrzucenie (przy znacznym udziale opozycji) w pierwszym czytaniu w sejmie projektu liberalizującego przepisy dotyczące aborcji (2018). Nie bez znaczenia jest również wyraźne starcie kampanii społecznych środowisk pro-life i pro-choice (wystawy przed szpitalami, billboardy etc.).

Trzeba w tym miejscu wspomnieć również o skali zjawiska, której ustalenie wcale nie jest takie proste. O ile przed rokiem 1988 można mówić o ok. 100 tys. aborcji rocznie, to w latach kolejnych ich liczba spadła do nieco po-

${ }^{15}$ Stan na marzec 2018 roku.

${ }^{16}$ Por.np. Mija 25 lat od uchwalenia tzw. ustawy antyaborcyjnej, w: Gazeta Prawna.pl, 07.01.2018, http://prawo.gazetaprawna.pl/artykuly/1096129,25-lat-temu-uchwalono-tzw-ustawe-antyabor cyjna.html [dostęp: 25.01.2018].

17 Por. np. Sprawa Tysiac przeciw Polsce (skarga nr5410_03), wyrok z 20 marca 2007 r. [tłumaczenie robocze Ministerstwa Sprawiedliwości], w: Trybunał Konstytucyjny, http://trybunal. gov.pl/polskie-akcenty-w-orzecznictwie-miedzynarodowym/rada-europy-europejski-trybunalpraw-czlowieka/w-sprawach-polskich/art/7999-sprawa-tysiac-przeciwko-polsce-skarga-nr-541003-wyrok-z-dnia-20-marca-2007-rtlumaczenie-robo/ [dostęp: 25.01.2018]. 
nad 11,5 tys. w roku 1992. Po roku 1993 sytuacja stała się bardziej skomplikowana ze względu na fakt, że oficjalne statystyki odnoszą się wyłącznie do aborcji wykonanych zgodnie z obowiązującymi przepisami - ich skalę obrazują wykresy nr 1 i nr 2 . Nie jest natomiast znana liczba aborcji wykonywanych „w podziemiu” - tutaj można odwołać się jedynie do szacunków, przy czym są one silnie zróżnicowane - środowiska pro-choice szacują liczbę aborcji na co najmniej 100 tys. rocznie (tak, jak przed rokiem 1988), natomiast środowiska pro-life wskazują na 1,5-5\% liczby urodzeń w danym roku (co przy ok. 400 tys. urodzeń w ostatnim czasie daje odpowiednio liczbę między 6 a 20 tys. - por. np. Gębka 2011, s. 37-55).

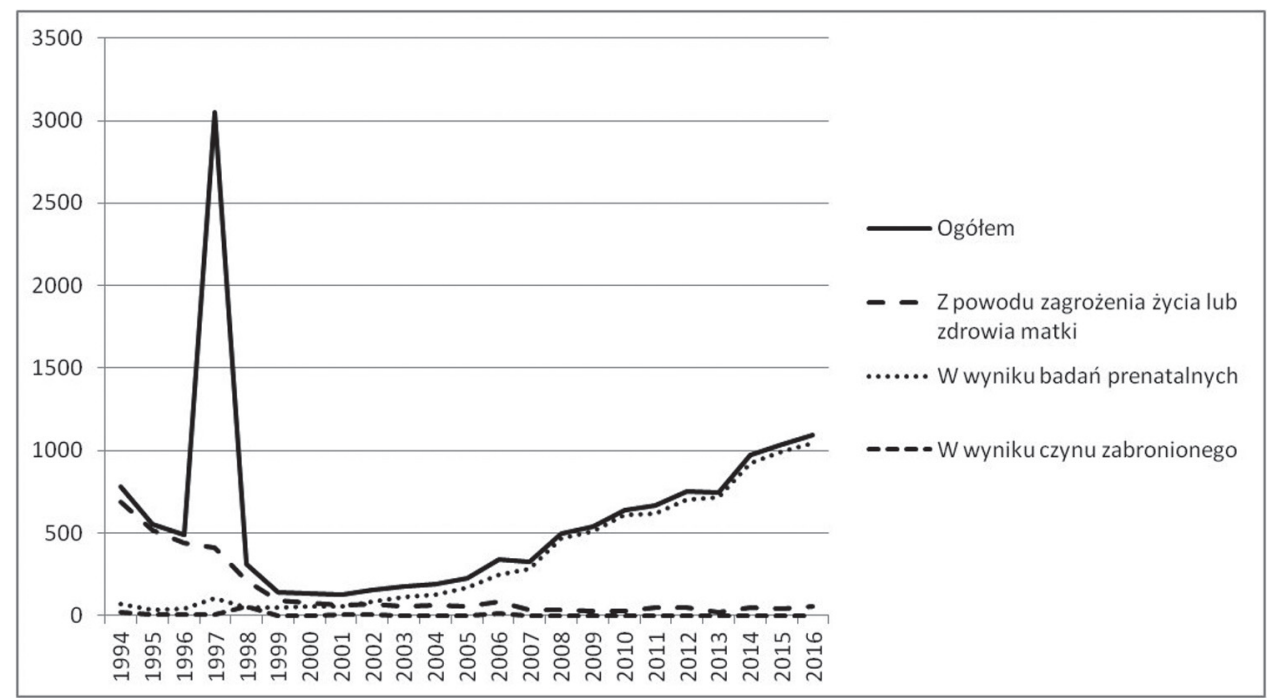

Wykres 1. Liczba legalnych aborcji w Polsce w latach 1994-2016 ${ }^{18}$

Liczba legalnych aborcji w przywołanym okresie początkowo wyraźnie spadała (z wyjątkiem roku 1997, w którym obowiązywała nowelizacja ustawy z roku 1993, wprowadzająca dopuszczalność aborcji na podstawie przesłanki „ciężkie warunki życiowe / trudna sytuacja osobista”), by po okresie względnej stabilizacji na dość niskim poziomie w pierwszej dekadzie XXI wieku, zacząć systematycznie rosnąć i przekroczyć 1 tys. w roku 2016. Zdecydowa-

18 Opracowanie własne na podstawie: Liczba aborcji $w$ Polsce - interpelacja, w: strona internetowa posła Jakuba Kuleszy, 22.09.2016, https://kulesza.pl/blog/2016/09/22/liczba-aborcjiw-polsce-interpelacja/ [dostęp: 25.01.2018]; MZ: W 2016 roku w Polsce wykonano ponad tysiąc aborcji, w: RMF24, 25.08.2017, http://twojezdrowie.rmf24.pl/aktualnosci/news-mz-w-2016-rokuw-polsce-wykonano-ponad-tysiac-aborcji,nId,2432919 [dostęp: 25.01.2018]. 
nie bardziej interesujące są dane dla poszczególnych przesłanek - by tendencje były lepiej widoczne, na wykresie 2 usunięto ogólną liczbę aborcji. Widać wówczas wyraźnie, że aborcje na podstawie przesłanki „czyn zabroniony” przeprowadzane są relatywnie rzadko (najwięcej w roku 1998 - 53, 1994 - 19, 2006 - 11, w pozostałych latach były to liczby jednocyfrowe, trzykrotnie nie odnotowano ich w ogóle). Natomiast w przypadku dwóch pozostałych przesłanek można zaobserwować w przywołanym okresie przeciwstawne tendencje: o ile liczba aborcji przeprowadzanych na podstawie przesłanki ,zagrożenie zdrowia lub życia matki" - pierwotnie dominująca - wyraźnie spadała w ostatniej dekadzie XX wieku, by po przełomie wieków ustabilizować się na względnie niskim poziomie (ostatni raz liczba aborcji wynikających z tej przesłanki przekroczyła $100 \mathrm{w}$ roku 1998), o tyle liczba aborcji dokonanych z przesłanki „duże prawdopodobieństwo upośledzenia/choroby płodu” (na wykresie opisane „w wyniku badań prenatalnych”) - czy mówiąc jeszcze inaczej - z przesłanki „eugenicznej”, która to liczba początkowo była niska, od przełomu wieków zaczęła rosnąć, w roku 2003 przekroczyła 100, a w roku $2016-1$ tys.

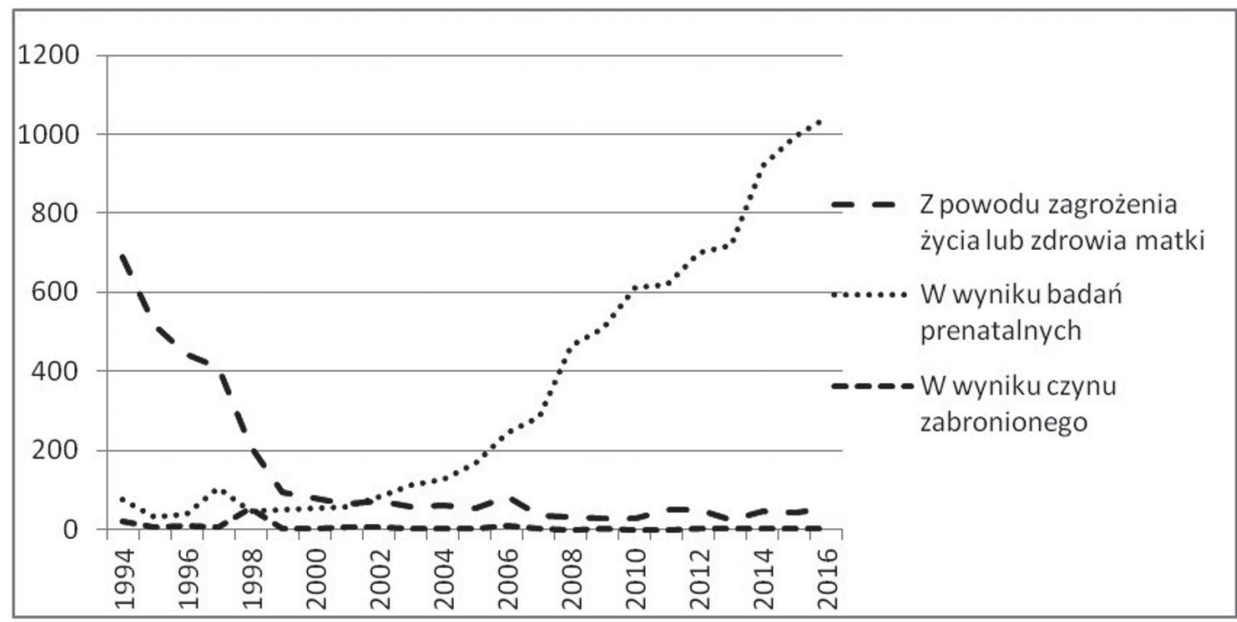

Wykres 2. Liczba legalnych aborcji w Polsce w latach 1994-2016 z podziałem na przesłanki ${ }^{19}$

Łącznie w latach 1994-2016 przeprowadzonych zostało 13958 legalnych aborcji, w tym: 2524 na podstawie obowiązującej w roku 1997 prze-

${ }^{19}$ Opracowanie własne na podstawie: Liczba aborcji $w$ Polsce..., dz. cyt., MZ: W 2016 roku $w$ Polsce..., dz. cyt. 
słanki „ciężkie warunki życiowe / trudna sytuacja osobista”, 139 na podstawie przesłanki „czyn zabroniony”, 3223 - „zagrożenie zdrowia lub życia matki” i wreszcie 8027 „w wyniku badań prenatalnych"20.

\section{Aborcja w badaniach opinii społecznej}

W badaniach opinii społecznej podejmowane są różne tematy - bardzo często są to tematy kontrowersyjne - jak chociażby opinia o dopuszczalności bądź niedopuszczalności aborcji, przy czym wyniki różnych badań nieraz diametralnie się od siebie różnią, co może wynikać np. z przebadanej próby, sposobu sformułowania pytań, momentu przeprowadzenia badań (kontekstu, w jakim są przeprowadzane) czy wreszcie sposobu interpretacji uzyskanych wyników. Warto w tym miejscu przywołać wyniki pewnych badań przeprowadzonych w latach 2016-2018. Portal RMF24 8 marca 2017 roku opublikował wyniki badania wykonanego przez instytut IPSOS na zlecenie Ordo Iuris. Wyniki te wskazywały, iż 60,2\% ankietowanych opowiadało się za pełną ochroną życia od momentu poczęcia, 22,1\% badanych było przeciwnego zdania. W informacji przywołane zostały również wyniki badań z maja 2016 roku, w przypadku których takie stanowiska zajęło odpowiednio 59\% i $27 \%$ badanych ${ }^{21}$. Tymczasem według badań, które zostały przeprowadzone przez IBRiS na zlecenie „Rzeczypospolitej” (data publikacji: 24.01.2018), za zaostrzeniem warunków dopuszczalności aborcji (ograniczeniem przesłanki „eugenicznej”) opowiadało się zaledwie 17\% respondentów, natomiast przeciw zaostrzeniu $-70,3 \%{ }^{22}$. Innymi słowy - ponad $2 / 3$ badanych IBRiS nie popierało pełnej ochrony życia, co więcej można nawet przyjąć, że było ich więcej - bo z owych $17 \%$ będących zwolennikami zaostrzenia niekoniecznie wszyscy musieli być zwolennikami zaostrzenia warunków w przypadku pozostałych przesłanek.

${ }^{20}$ Obliczenia własne na podstawie: Liczba aborcji w Polsce..., dz. cyt., MZ: W 2016 roku $w$ Polsce..., dz. cyt. Dane te mogą być jednak niepełne - mogą nie uwzględniać danych ze szpitali podlegających MSWiA - w których np. roku 2016 przeprowadzono przynajmniej 2 aborcje, nieuwzględnione w oficjalnych statystykach. Por. Legalnych aborcji w Polsce jest więcej. I to wcale nie z tego powodu, o którym myślicie, w: Gazeta.pl, 01.02.2018, http://wiadomosci.gazeta.pl/wia domosci/7,114883,22967897,legalnych-aborcji-w-polsce-jest-wiecej-i-to-wcale-nie-z-tego.html [dostęp: 30.03.2018].

${ }^{21}$ Ordo Iuris: postulaty feministek sq obce dla większości Polek, w: RMF24, 08.03.2017, http://www.rmf24.pl/fakty/polska/news-ordo-iuris-postulaty-feministek-sa-obce-dla-wiekszoscipolek,nId,2365835 [dostęp: 25.01.2018].

22 Por. Z. Dąbrowska, Badani chca, by w przypadku nieusuwalnej i ciężkiej wady płodu, aborcja wciaż była legalna $i$ dostęnna, w: www.rp.pl, 24.01.2018, http://www.rp.pl/Spor-oaborcje/301249914-Sondaz-Polacy-nie-chca-zaostrzania-przepisow-aborcyjnych.html [dostęp: 26.01.2018]. 
Wyniki badań dotyczących aborcji są bądź w dyspozycji zamawiającego konkretne badanie - wówczas poznać można tylko wybrane informacje, często poddane już wstępnej interpretacji, bądź też są dostępne szersze raporty $\mathrm{z}$ badań, dające głębszy wgląd w odpowiedzi respondentów (jak również np. w sposób sformułowania pytań). Dlatego w dalszej części niniejszego artykułu zostaną przywołane te badania, które pozwalają właśnie na głębszy wgląd, a które były prowadzone przez dwa ośrodki badania opinii publicznej: Centrum Badania Opinii Społecznej (CBOS) oraz Ośrodek Badania Opinii Publicznej (OBOP) lub instytucje będące jego kontynuatorami ${ }^{23}$.

Od roku 1989 oba wspomniane ośrodki badawcze przeprowadziły przynajmniej 49 badań dotyczących bezpośrednio lub pośrednio aborcji (CBOS -32 , w tym bezpośrednio dotyczące aborcji -25 , OBOP i jego następcy -18 , w tym bezpośrednio dotyczące aborcji - 12). Jednakże, pomimo pozornego bogactwa raportów, ze względów metodologicznych, takich, jak chociażby sposób sformułowania pytań czy ich powtarzalność w różnych badaniach, jak również sposób prezentacji wyników w raportach, nie jest możliwe porównanie wyników wszystkich tych badań. Dlatego kiedy analizowane będzie ogólne stanowisko respondentów wobec aborcji, wziętych zostanie pod uwagę 12 badań z lat 1991-2011, natomiast w odniesieniu do poszczególnych przesłanek - 15 badań z lat 1992-2016, z wyjątkiem przesłanki „trudna sytuacja osobista/ /materialna", gdzie wzięto pod uwagę 20 badań. Zestawienie badań wykorzystanych do analiz zawiera tabela 1 . Należy w tym miejscu zaznaczyć, że badania nie były realizowane w równych odstępach czasu i np. trzy badania $\mathrm{z}$ tych, które prezentują ogólny stosunek do aborcji, były wykonane w ciągu 1 roku kalendarzowego, podobna sytuacja zaistniała w przypadku analiz konkretnych przesłanek.

Tabela 1. Zestawienie badań wykorzystanych w analizach

\begin{tabular}{|c|c|c|c|c|c|}
\hline $\begin{array}{c}\text { Data } \\
\text { publikacji }\end{array}$ & $\begin{array}{c}\text { Ośrodek } \\
\text { badawczy }\end{array}$ & $\begin{array}{c}\text { Numer } \\
\text { komunikatu }\end{array}$ & $\begin{array}{c}\text { Data } \\
\text { publikacji }\end{array}$ & $\begin{array}{c}\text { Ośrodek } \\
\text { badawczy }\end{array}$ & $\begin{array}{c}\text { Numer } \\
\text { komunikatu }\end{array}$ \\
\hline III.1991 & CBOS & BS/111/35/91 & XI.2002 & CBOS & BS/191/2002 \\
\hline XI.1992 & CBOS & BS/409/104/92 & IX.2003 & CBOS & BS/139/2003 \\
\hline VII.1994 & OBOP & $43 / 94$ & II.2005 & CBOS & BS/37/2005 \\
\hline VII.1995 & OBOP & $73 / 95$ & XI.2006 & CBOS & BS/173/2006 \\
\hline I.1996 & CBOS & BS/4/4/96 & X.2007 & CBOS & BS/152/2007 \\
\hline
\end{tabular}

${ }^{23}$ OBOP, TNS OBOP, KANTAR. 


\begin{tabular}{|c|c|c|c|c|c|}
\hline $\begin{array}{c}\text { Data } \\
\text { publikacji }\end{array}$ & $\begin{array}{c}\text { Ośrodek } \\
\text { badawczy }\end{array}$ & $\begin{array}{c}\text { Numer } \\
\text { komunikatu }\end{array}$ & $\begin{array}{c}\text { Data } \\
\text { publikacji }\end{array}$ & $\begin{array}{c}\text { Ośrodek } \\
\text { badawczy }\end{array}$ & $\begin{array}{c}\text { Numer } \\
\text { komunikatu }\end{array}$ \\
\hline III.1996 & OBOP & $32 / 96$ & VII.2010 & CBOS & BS/100/2010 \\
\hline X.1996 & CBOS & BS/152/150/96 & IX.2011 & CBOS & BS/102/2011 \\
\hline XI.1996 & CBOS & BS/176/174/96 & XII.2012 & CBOS & BS/160/2012 \\
\hline I.1997 & OBOP & $002 / 97$ & IV.2016 & CBOS & BS/51/2016 \\
\hline VII.1997 & CBOS & BS/97/97/97 & V.2016 & CBOS & BS/71/2016 \\
\hline II.1998 & CBOS & BS/20/20/98 & X.2016 & CBOS & BS/144/2016 \\
\hline VIII.1999 & CBOS & BS/127/99 & - & - & - \\
\hline
\end{tabular}

Trzeba wspomnieć w tym miejscu o jeszcze jednej (dość oczywistej) kwestii: badanie opinii publicznej w pewnym sensie jest „fotografią” rzeczywistości w danym momencie, która może być w jakiś sposób zaburzona, zakłócona przez okoliczności, w jakich została wykonana ${ }^{24}$. Dlatego łączna analiza kilku takich „fotografii” pozwala uzyskać bardziej obiektywny obraz.

Jeśli chodzi o ogólny stosunek do aborcji, to w analizowanych tu badaniach respondenci odpowiadali zasadniczo w następujący sposób - aborcja jest: (a) dopuszczalna, (b) dopuszczalna warunkowo, (c) niedopuszczalna z wyjątkami, (d) niedopuszczalna, (e) trudno powiedzieć. O ile odpowiedzi „dopuszczalna” i „niedopuszczalna” są oczywiste i nie budzą wątpliwości interpretacyjnych jako stanowiska pro-choice i pro-life, o tyle odpowiedzi ,pośrednie" dają możliwość włączenia ich - jako słabszych wersji - do stanowiska pro-choice lub pro-life, a w skrajnych przypadkach nawet obie po jednej lub po drugiej stronie - jako stanowiska przeciwne pełnej ochronie życia (wykres 3) lub nieograniczonej dopuszczalności aborcji (wykres 4). Widać, że stanowiska skrajnie pro-life i pro-choice mają zbliżone odsetki wskazań, które wahają się w przedziale ok. 10-20\% (,dopuszczalna” - 7-23\%, „niedopuszczalna" - 10-18\%). Oznacza to, że w skrajnych przypadkach można interpretować, że pozostała część respondentów (ok. 70-90\%) opowiada się - zależnie od przyjętego przez interpretującego stanowiska - albo przeciw całkowitej dopuszczalności aborcji, albo przeciw bezwzględnej ochronie życia.

${ }^{24}$ Taka sytuacja miała miejsce w przypadku badania z listopada 2006 (kiedy podjęta została próba wprowadzenia zapisu o ochronie życia do konstytucji), gdzie wyniki wyraźnie odbiegają od wyników innych badań. Z informacji, jakie w raporcie zamieścił CBOS, wynika, że w trakcie trwania badań, kiedy część wywiadów już została przeprowadzona, został opublikowany apel arcybiskupa Józefa Michalika do parlamentarzystów o wprowadzenie stosownego zapisu w konstytucji, co mogło spowodować brak szczerości części respondentów (z obawy przed wyrażeniem opinii niezgodnej z głosem Kościoła - por. Komunikat z badań CBOS 2006). 


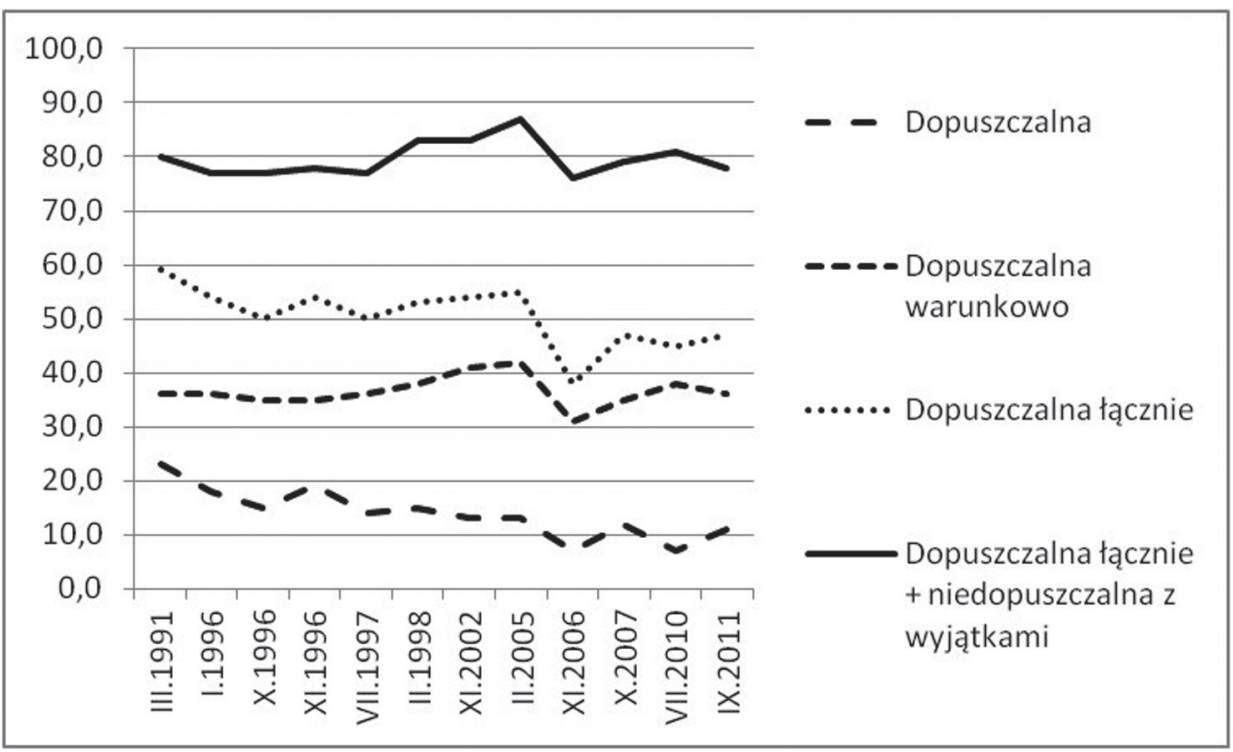

Wykres 3. Odsetek odpowiedzi, które nie wykluczają całkowicie dopuszczalności aborcji

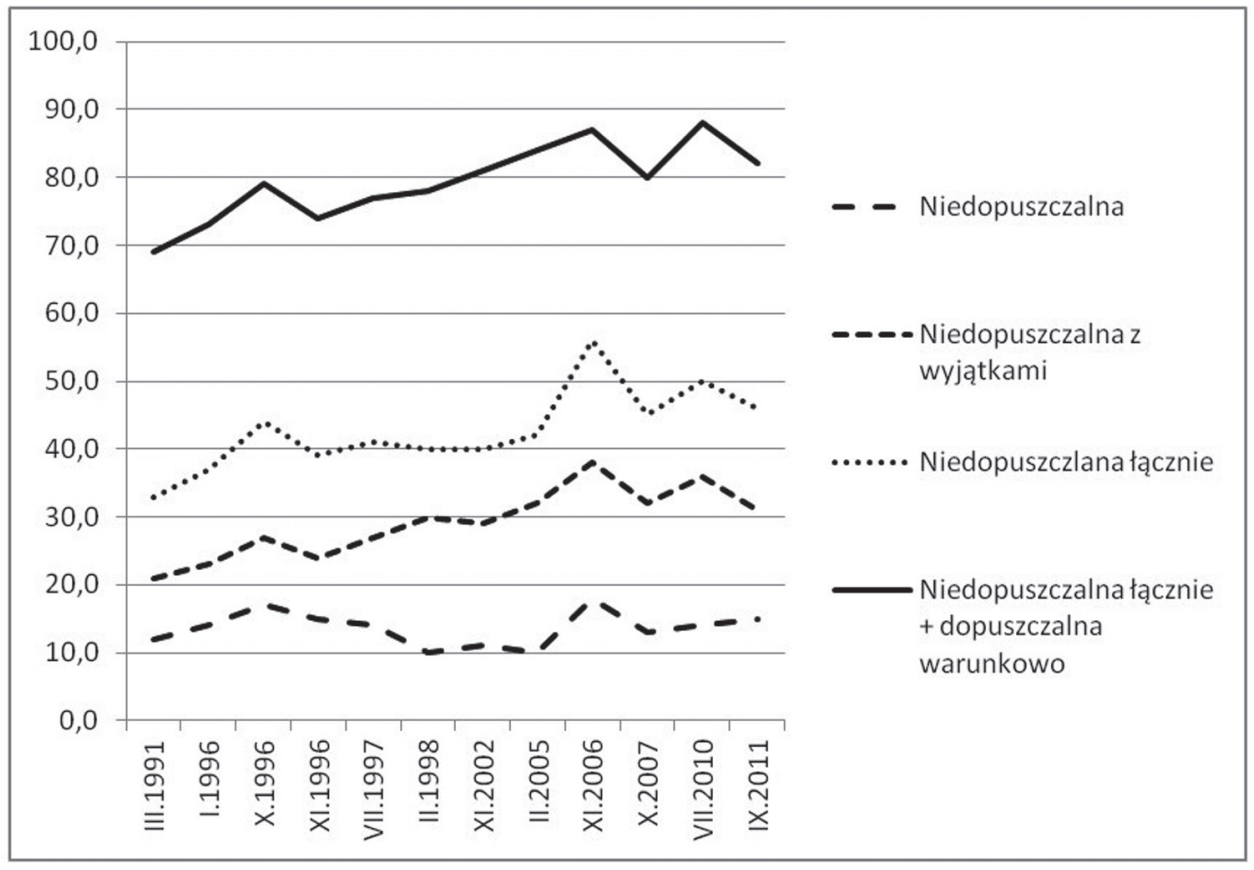

Wykres 4. Odsetek odpowiedzi wykluczających nieograniczoną dopuszczalność aborcji 
Można jednak wyniki przywołanych badań zinterpretować nieco inaczej, łącząc razem odpowiedzi „dopuszczalna warunkowo” i „niedopuszczalna z wyjątkami” (jak na wykresie 5). Odsetek takich połączonych odpowiedzi (które można uznać za głos z tzw. „kompromisem aborcyjnym”) w analizowanych badaniach wahał się w przedziale $57-74 \%$ (przy czym od początku XXI wieku nie spadł poniżej 67\%). Wyniki te można zestawić z rezultatami przywołanego wcześniej badania dla „Rzeczypospolitej” (70,3\% respondentów nie chciało zaostrzenia obecnie obowiązujących przepisów - wynik ten został dodany dla porównania na wykresie 5 i oznaczony „2018*”), które - jak widać - nie odbiegają specjalnie od wyników wspomnianych badań (jeśli chodzi o odpowiedzi „kompromisowe”).

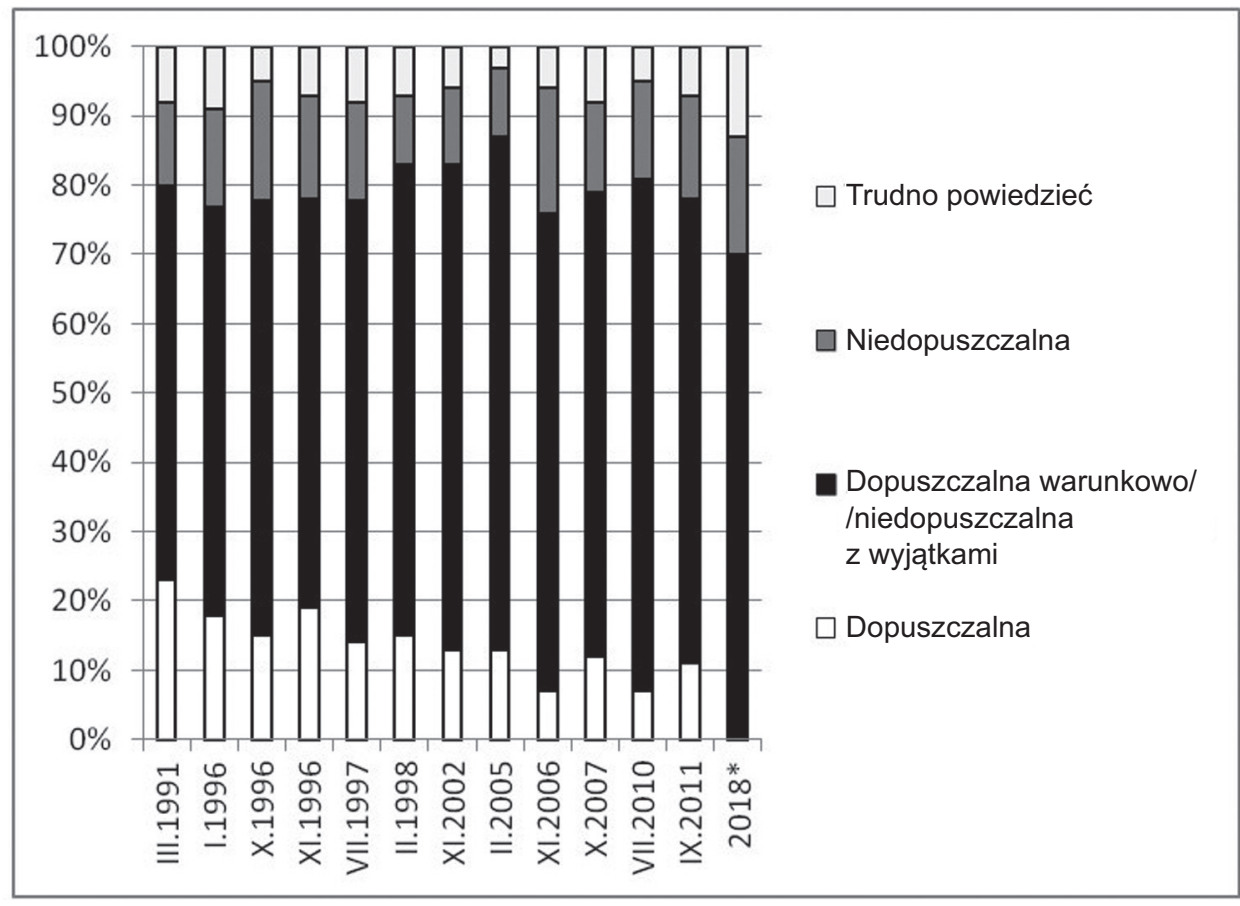

Wykres 5. Dopuszczalność aborcji (w procentach)

Część badań opinii społecznej pozwala spojrzeć jednak trochę głębiej w stanowiska badanych i przyjrzeć się ich stosunkowi do poszczególnych przyczyn aborcji, które - zdaniem badanych - usprawiedliwiają bądź nie dopuszczalność aborcji. W badaniach brane były pod uwagę przesłanki zapisane w ustawie z roku 1993 („,czyn zabroniony”, „,wady/choroby płodu”, „,̇y- 


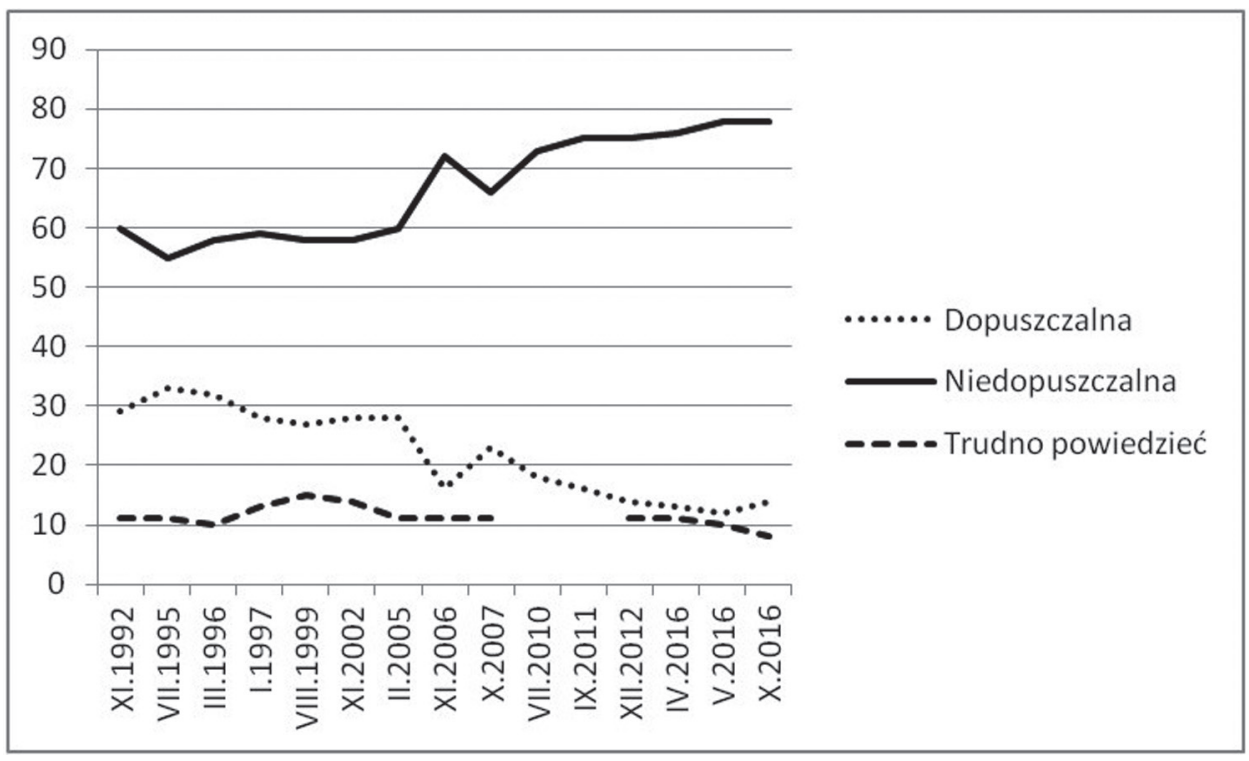

Wykres 6. Dopuszczalność aborcji w sytuacji, kiedy kobieta nie chce mieć dziecka (w procentach)

cie i zdrowie matki”), ale również „trudna sytuacja materialna i/lub osobista” (przesłanka z nowelizacji z drugiej połowy lat dziewięćdziesiątych XX wieku) czy wreszcie sytuacja, że kobieta nie chce mieć dziecka ${ }^{25}$.

Ostatnią z wymienionych przesłanek można uznać za mniej lub bardziej zbliżoną do sytuacji, kiedy respondenci byli pytani o dopuszczalność aborcji w ogóle. Gdy pojawiało się pytanie o dopuszczalność aborcji, kiedy kobieta po prostu nie chce mieć dzieci (a więc w sytuacji, kiedy aborcja jest traktowana jako narzędzie ograniczania liczby potomstwa czy swoisty „zamiennik” antykoncepcji), to zasadniczo takie rozwiązanie nigdy nie było akceptowane przez większość respondentów, a odsetek tych, którzy je odrzucali, systema-

${ }^{25}$ Dostępne raporty nie zawsze prezentują wszystkie przesłanki, czasem również nie przedstawiają wszystkich możliwych odpowiedzi, stąd na kolejnych wykresach występują czasem przerwy. Dodatkowo w przypadku 2 grup przesłanek w części badań w jednym pytaniu łączono więcej niż jedną przesłankę, a w późniejszych badaniach rozdzielano je na odrębne pytania. Chodzi tu o „życie i/lub zdrowie matki” oraz „trudną sytuację materialną i/lub osobistą”. W raportach przy pytaniach o dopuszczalność aborcji w poszczególnych przypadkach odpowiedzi były prezentowane jako „tak” lub „nie”, względnie były jeszcze podzielone na „zdecydowanie tak”, „raczej tak”, „raczej nie” i „zdecydowanie nie” - wówczas na potrzeby niniejszego opracowania łączone były odpowiedzi „zdecydowanie tak” i „raczej tak” oraz „zdecydowanie nie” i „raczej nie”. 
tycznie rósł przez niemal ćwierć wieku - od ok. 60\% w roku 1992 do niemal $80 \%$ w roku 2016, co dobrze widać na wykresie 6. Obrazuje on również kwestię, o której była mowa wcześniej - a mianowicie problem wrażliwości badań na kontekst, w jakim są one prowadzone - wyniki badań z roku 2006 nie pasują do ogólnej tendencji, niemniej jednak jest to badanie, co do którego CBOS zwrócił uwagę na zaburzenie wyników ${ }^{26}$.

Jeśli chodzi o drugą z przesłanek, która obecnie nie obowiązuje - „trudną sytuację materialną i/lub osobistą" (wykres 7) - to również tutaj odrzucenie dopuszczalności aborcji w takiej sytuacji zdecydowanie wzrosło w analizowanym okresie - o ile w latach dziewięćdziesiątych odrzucało ją 18-46\% respondentów (obie przesłanki ujęte łącznie), to w wieku XXI odsetek odrzucających każdą z tych dwóch przesłanek z osobna wzrósł wyraźnie, osiągając w przypadku sytuacji osobistej nawet $80 \%$ (maj 2016).

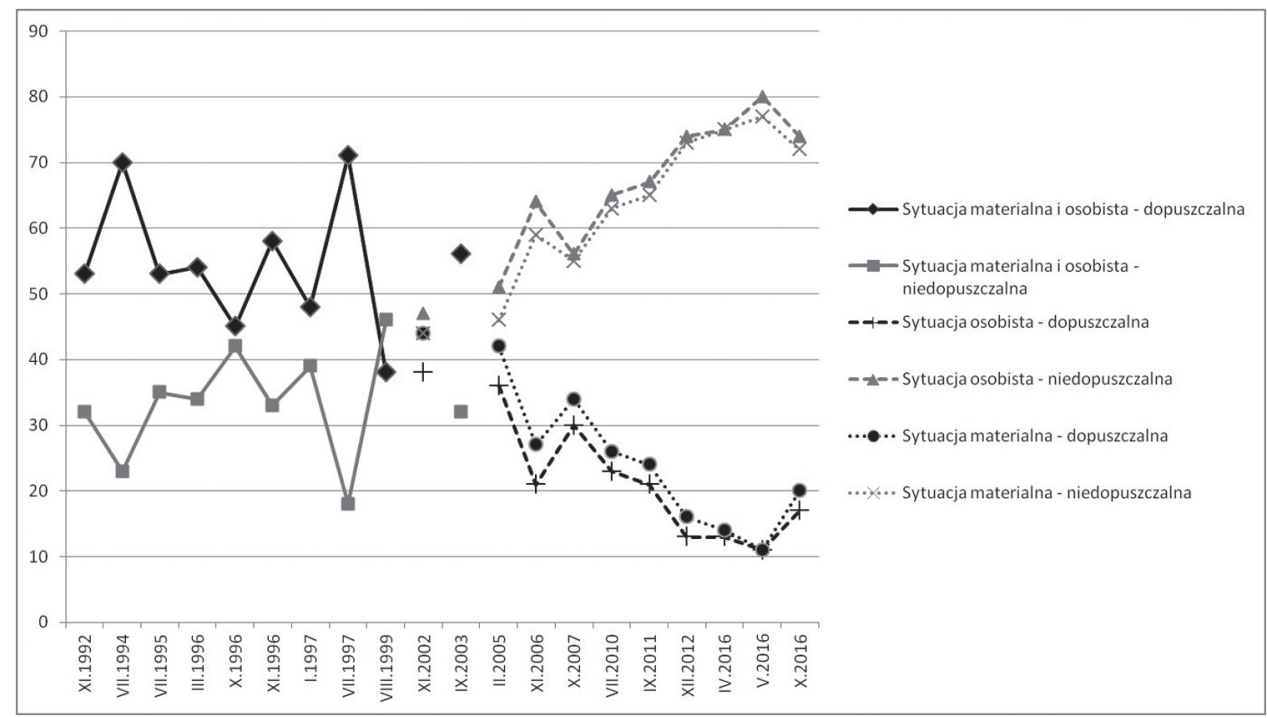

Wykres 7. Dopuszczalność aborcji w przypadku trudnej sytuacji materialnej i/lub osobistej (w procentach)

Jednakże, jeśli chodzi o przesłanki z ustawy z 1993 roku, to w ich przypadku większość respondentów jest skłonna uznać aborcję za dopuszczalną, choć poziom poparcia jest zróżnicowany, zależnie od przesłanki. W przypadku „życia i/lub zdrowia matki” zdecydowana większość respondentów dopuszczała aborcję, przy czym o ile przy pytaniu o samo zdrowie odsetek wskazań

${ }^{26}$ Por. przypis nr 24. 
dopuszczających aborcję znajdował się w przedziale $71-85 \%$, to w przypadku pytań o życie matki odsetek odpowiedzi dopuszczających aborcję był zawsze wyższy (nawet 91\%).

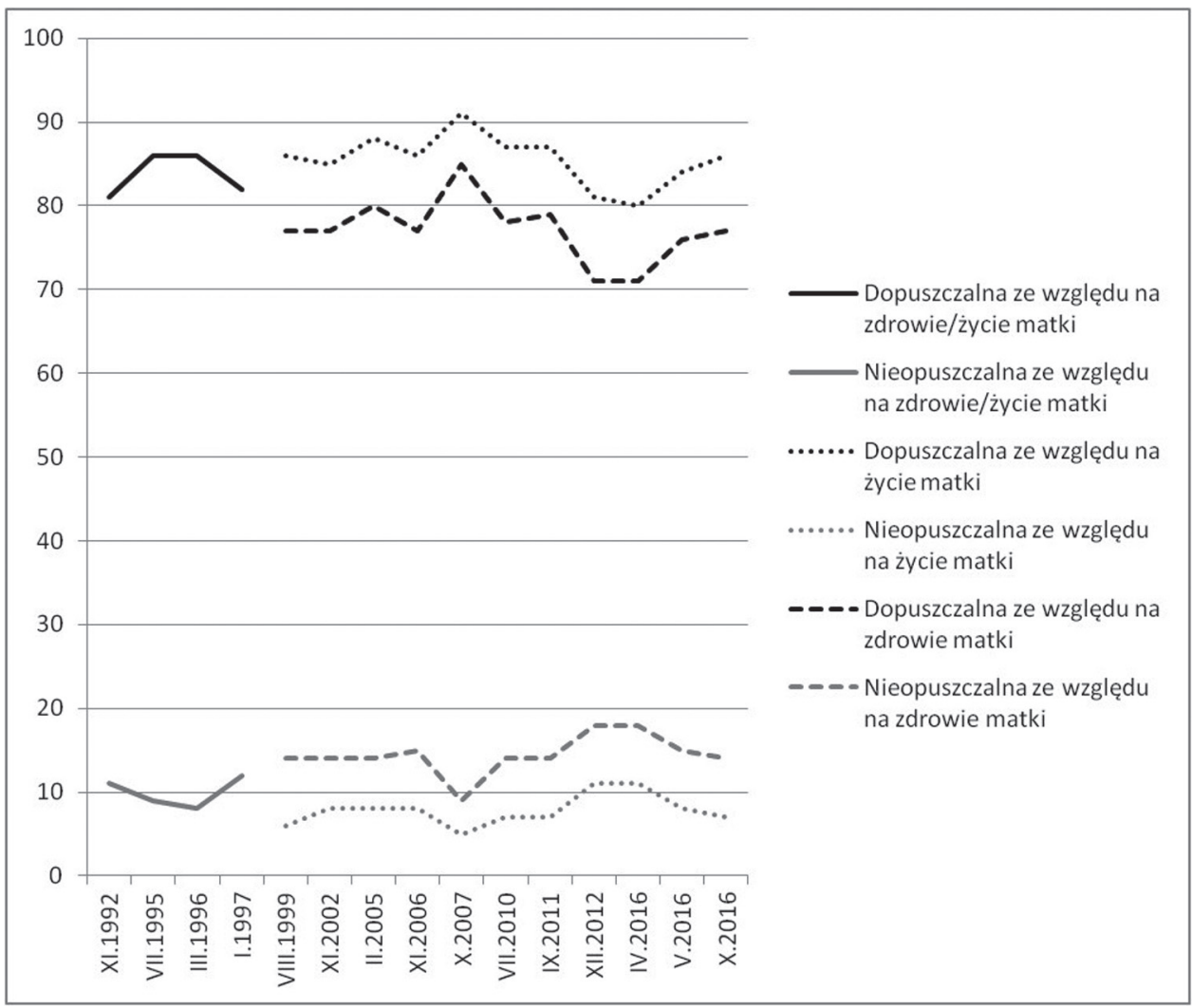

Wykres 8. Dopuszczalność aborcji w sytuacji zagrożenia życia i/lub zdrowia matki $(\mathrm{w} \text { procentach })^{27}$

Podobnie wysokim poparciem cieszyła się dopuszczalność aborcji w związku z przesłanką , ,czyn zabroniony”, którą dopuszczało w analizowanym okresie $72-84 \%$ respondentów.

${ }^{27}$ Ze względu na przejrzystość wykresu zrezygnowano z prezentacji na nim odpowiedzi ,trudno powiedzieć". 


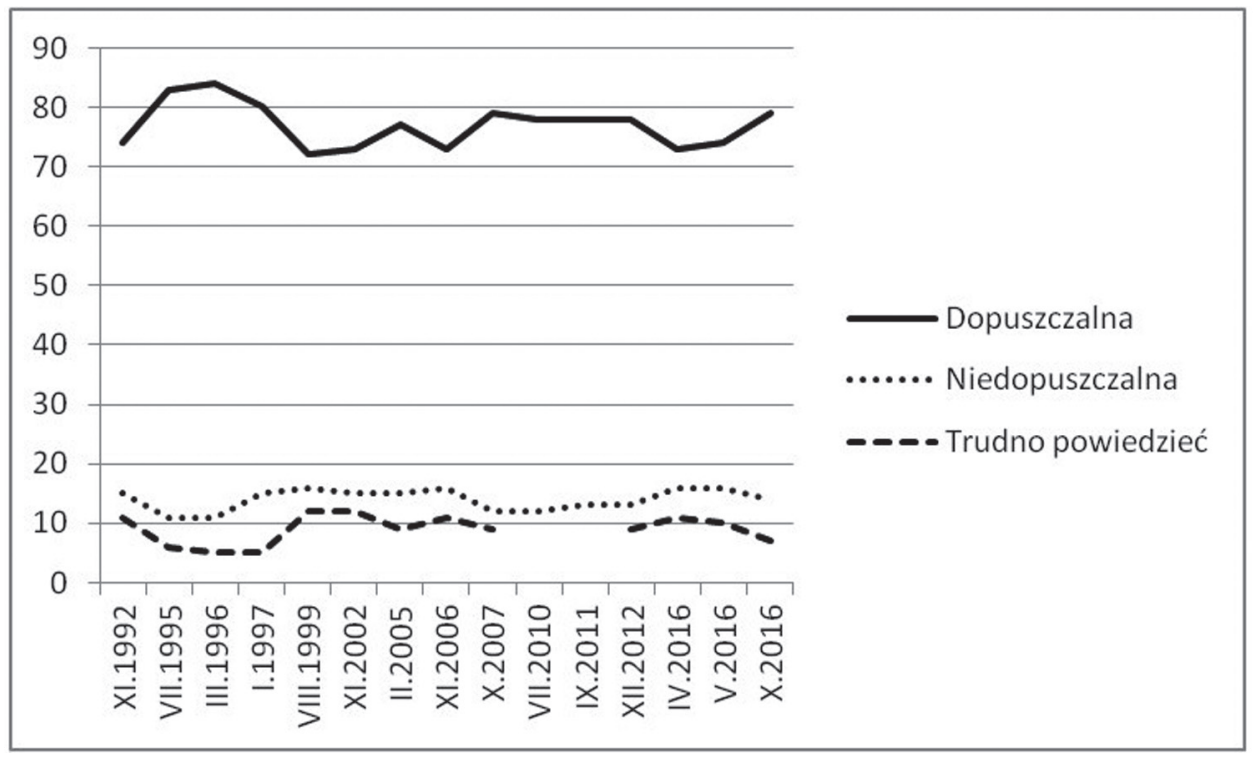

Wykres 9. Dopuszczalność aborcji w przypadku ciąży będącej skutkiem czynu zakazanego

Nieco inaczej wygląda sytuacja w przypadku ostatniej z przesłanek ustawowych - „dużego prawdopodobieństwa wad/chorób płodu”. Wprawdzie nadal zdecydowana większość respondentów dopuszcza aborcję również w przypadku tej przesłanki, jednakże o ile jeszcze w latach dziewięćdziesiątych było to nawet ponad $80 \%$ respondentów ( $83 \%$ w roku 1995), to pod koniec wspomnianej dekady zauważalny jest spadek i względna stabilizacja poparcia na poziomie około $60 \%$ (w badaniu z kwietnia 2016 roku było to „tylko” 53\%) przy równoczesnym wzroście odsetka respondentów przeciwnych aborcji w tej sytuacji (z 9\% w roku 1992 do nawet 30\% w kwietniu roku 2016).

Warto w tym miejscu zatrzymać się na chwilę przy trzech obowiązujących przesłankach ustawowych dopuszczalności aborcji ${ }^{28}$ i przyjrzeć się im w kontekście liczby legalnie wykonywanych aborcji oraz akceptacji przez respondentów dopuszczalności aborcji. W przypadku tych przesłanek dopuszczalności aborcji, które cieszą się wysokim poparciem („,czyn zakazany”, ,życie i/lub zdrowie matki") liczba faktycznie wykonywanych aborcji jest albo znikoma (dla przypomnienia - w latach 1994-2016 dokonanych zostało łącznie 139 aborcji z przesłanki czyn zakazany), albo wyraźnie spadła na początku XXI wieku. Z kolei w przypadku przesłanki „eugenicznej” spadkowi (a później sta-

\footnotetext{
${ }^{28}$ Stan na marzec 2018 roku.
} 


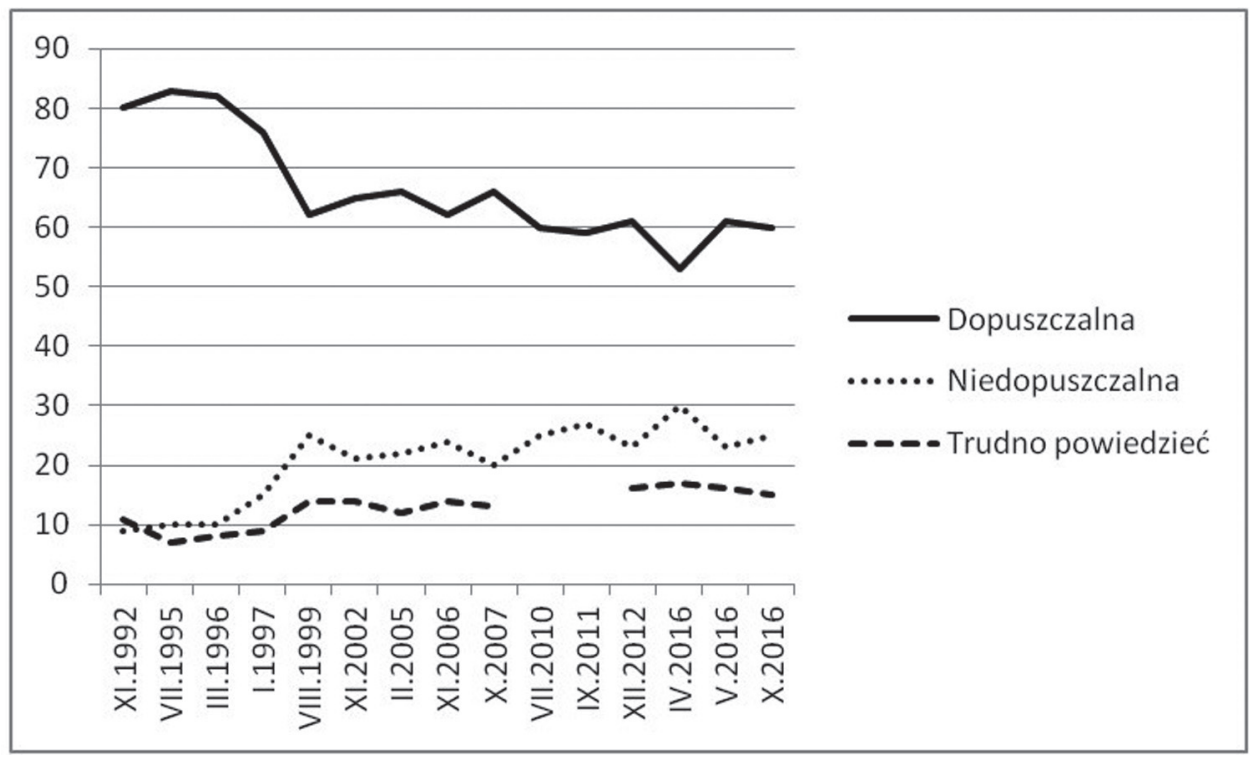

Wykres 10. Dopuszczalność aborcji w przypadku dużego prawdopodobieństwa wad/ /chorób płodu

bilizacji) poparcia towarzyszy ogromy wzrost liczby wykonywanych legalnie aborcji (w porównaniu z rokiem 1995, kiedy aborcji „eugenicznych” odnotowano 33, w roku 2016 odnotowano 1042 takie aborcje - a więc 3157,58\% [SIC!] liczby z roku 1995) - co niewątpliwie można uznać za powód do niepokoju.

\section{Wnioski}

Analizując odpowiedzi respondentów, można przyjąć, że aborcja nie jest przez nich traktowana jako narzędzie kształtowania liczby potomstwa, o czym świadczy dość niski odsetek respondentów dopuszczających aborcję bez ograniczeń czy wysoki odsetek respondentów, którzy odrzucają aborcję w sytuacji, kiedy kobieta nie chce mieć dziecka. Przemawia za tym również systematyczny wzrost odsetka odpowiedzi odrzucających aborcję z tzw. ,przyczyn społecznych”. W tym aspekcie poglądy respondentów można uznać za zbliżone do stanowiska encykliki Humanae vitae. Jednakże jeśli chodzi o przesłanki ustawowe dopuszczalności aborcji (według ustawy z roku 1993), to wyraźnie widać, że większość respondentów nie jest skłonna z nich zrezygnować - nawet w przypadku przesłanki „eugenicznej”, w przypadku której, pomimo 
spadku poparcia, ok. 3/5 respondentów nadal popierało dopuszczalność aborcji (odwołując się do ostatniego dostępnego raportu) - zatem trudno mówić o całkowitym odrzuceniu aborcji (ma bowiem ona być - zdaniem respondentów - dostępna przynajmniej w sytuacjach „kryzysowych”).

Można oczywiście postawić pytanie, czy inny sposób formułowania pytań przez ośrodki badawcze skutkowałby zmianą $\mathrm{w}$ odpowiedziach respondentów - np. gdyby pytanie zamiast formy „czy jest Pan/Pani za dopuszczalnością aborcji w sytuacji, kiedy ciąża zagraża życiu i/lub zdrowiu matki”, miało formę „czy jest Pan/Pani za możliwością zabicia nienarodzonego dziecka w sytuacji, kiedy ciąża zagraża życiu i/lub zdrowiu matki”? Odpowiedź wydaje się twierdząca, jednakże trudno ocenić, czy zmiana byłaby znaczna. Trudno również spodziewać się, że zostanie wprowadzona druga forma pytania (chyba że będą to badania realizowane na konkretne zamówienie). Co więcej - wcale nie jest pewne, czy respondent, udzielając odpowiedzi przeczącej na pytanie sformułowane w drugi sposób, nie udzielałby jej ze względu na sformułowanie w nim użyte, wcale nie będąc przekonanym, że jest to jego stanowisko (np. z obawy przed reakcją ankietera). Kwestia ta może być niewątpliwie przedmiotem odrębnych analiz, dotyczących relacji świadomości respondentów i języka używanego czy to w przekazie treści dotyczących aborcji, czy w badaniach nad aborcją.

W tym kontekście trzeba zauważyć, że jeśli decydenci, kształtując politykę państwa, zwracają się choć trochę w kierunku badań opinii społecznej (co wydaje się oczywiste), to jakkolwiek w styczniu 2018 roku polski sejm przyjął do dalszych prac tylko projekt ustawy, który usuwa przesłankę ,eugeniczną”, odrzucając projekt liberalizujący przepisy, nie oznacza to wcale, że wejdzie on szybko w życie, co więcej - niekoniecznie będzie on dalej sprawnie procedowany.

THE (UN)ACCEPTABLE METHOD OF REGULATING BIRTHS? SOME REFLECTIONS ON ABORTION IN THE SOCIAL CONSCIOUSNESS OF POLES (ON THE BASE OF PUBLIC OPINION POLLS)

\section{Abstract}

The Humanae Vitae Encyclical lists abortion among illicit means of regulating birth. Since 1993 abortion has been legal in Poland only in three instances: when the pregnancy is a result of criminal offense, when it poses risk to the life and health of the mother and when there is high probability of fetal defects. Public opinion polls conducted since the 1990s show that while Poles are against abortion „on demand" 
(and against using abortion as a method of regulating birth), they are inclined to accept abortion in the cases in which it is permitted by law (especially when the pregnancy results from a criminal act or when it poses a risk to the life or health of the mother).

Keywords: abortion; public opinion polls

Slowa kluczowe: aborcja; badania opinii publicznej

\section{BIBLIOGRAFIA}

Adamski F. (2002), Rodzina. Wymiar społeczno-kulturowy, Kraków 2002.

Gębka M. (2011), Funkcja prokreacyjna na rozdrożu?, „Roczniki Socjologii Rodziny”, t. XXI, s. $37-55$.

Goldberg M. (2011), Wojny reprodukcyjne. Płeć, władza a przyszłość świata, Warszawa.

Holzer J. (2006), Demograficzne uwarunkowania polityki społecznej, w: Polityka społeczna, red. A. Kurzynowski, wyd. 3, Warszawa, s. 21-36.

Komunikat z badań CBOS (1991), Prawo o aborcji w opinii spoleczeństwa, Warszawa, CBOS, 1991, BS/111/35/91.

Komunikat z badań CBOS (1992), Opinia społeczna o przerywaniu ciąży, Warszawa, CBOS, 1992, BS/409/104/92.

Komunikat z badań OBOP (1994), Polacy o prawnym zakazie przerywania ciązy, Warszawa, Telewizja Polska S.A. OBOP, 1994, 43/94.

Komunikat z badań OBOP (1995), Polacy o aborcji, Warszawa, Telewizja Polska S.A. OBOP, 1995, 73/95.

Komunikat z badań CBOS (1996a), Kwestie ideologiczne: prywatyzacja, bezrobocie, aborcja, konkordat, Warszawa, CBOS, 1996, BS/4/4/96.

Komunikat z badań CBOS (1996b), Nowelizacja ustawy antyaborcyjnej i jej konsekwencje, Warszawa, CBOS, 1996, BS/176/174/96.

Komunikat z badań OBOP (1996c), Opinie o dopuszczalności aborcji, Warszawa, OBOP, 1996, $32 / 96$.

Komunikat z badań CBOS (1996d), Stosunek do aborcji wobec liberalizacji przepisów jej dotyczqcych, Warszawa, CBOS, 1996, BS/152/150/96.

Komunikat z badań OBOP (1997a), Czy przerywanie ciązy powinno być dozwolone, czy nie?, Warszawa, OBOP, 1997, 002/97.

Komunikat z badań CBOS (1997b), Stosunek do aborcji po orzeczeniu Trybunału Konstytucyjnego, Warszawa, CBOS, 1997, BS/97/97/97.

Komunikat z badań CBOS (1998), Stosunek do aborcji po zaostrzeniu przepisów aborcyjnych, Warszawa, CBOS, 1998, BS/20/20/98.

Komunikat z badań CBOS (1999), Młodzież i dorośli o aborcji, Warszawa, CBOS, 1999, BS/127/99.

Komunikat z badań CBOS (2002), Opinie o prawie do aborcji, Warszawa, CBOS, 2002, BS/191/2002.

Komunikat z badań CBOS (2003), Opinie o prawnej regulacji przerywania ciąży, Warszawa, CBOS, 2003, BS/139/2003.

Komunikat z badań CBOS (2005), Aborcja, edukacja seksualna, zaptodnienie pozaustrojowe, Warszawa, CBOS, 2005, BS/37/2005.

Komunikat z badań CBOS (2006), Postawy wobec aborcji, Warszawa, CBOS, 2006, BS/173/2006.

Komunikat z badań CBOS (2007), Opinie na temat aborcji, Warszawa, CBOS, 2007, BS/152/2007. 
Komunikat z badań CBOS (2010), Opinie na temat dopuszczalności aborcji, Warszawa, CBOS, 2010, BS/100/2010.

Komunikat z badań CBOS (2011), Opinie o prawnej dopuszczalności i regulacji aborcji, Warszawa, CBOS, 2011, BS/102/2011.

Komunikat z badań CBOS (2012), Opinie o prawie aborcyjnym, Warszawa, CBOS, 2012, BS/160/2012.

Komunikat z badań CBOS (2016a), Dopuszczalność aborcji w różnych sytuacjach, Warszawa, CBOS, 2016, BS/71/2016, ISSN 2353-5822.

Komunikat z badań CBOS (2016b), Jakiego prawa aborcyjnego oczekuja Polacy, Warszawa, CBOS, 2016, BS/144/2016, ISSN 2353-5822.

Komunikat z badań CBOS (2016c), Opinie o dopuszczalności aborcji, Warszawa, CBOS, 2016, BS/51/2016, ISSN 2353-5822.

Tyszka Z. (2001), System metodologiczny wieloaspektowej integralnej analizy życia rodzinnego, wyd. 2, Poznań.

Ustawa z dnia 27 kwietnia 1956 r. o warunkach dopuszczalności przerywania ciąży, Dz.U. z 1956 r., nr 12 , poz. 61 , art. 1 par. 1 .

Ustawa z dnia 7 stycznia 1993 o planowaniu rodziny, ochronie plodu ludzkiego i warunkach dopuszczalności przerywania ciąży, Dz.U. z 1993 r., nr 17, poz. 78.

\section{Publikacje internetowe}

Dąbrowska Z., Badani chca, by w przypadku nieusuwalnej i ciężkiej wady płodu, aborcja wciąż była legalna $i$ dostępna, w: www.rp.pl, 24.01.2018, http://www.rp.pl/Spor-o-aborcje/301249914Sondaz-Polacy-nie-chca-zaostrzania-przepisow-aborcyjnych.html [dostęp: 26.01.2018].

Gennarini S., UN pushes for international law to make abortion a human right, w: LIFESITE, 21.09.2017, https://www.lifesitenews.com/opinion/un-pushes-for-international-law-to-make-ab ortion-a-human-right [dostęp: 25.03.2018].

Gennarini S., UN Says Women Who Want to „Avoid Pregnancy” Should Use Abortion as Family Palnning, w: LifeNews.com, 20.04.2017, http://www.lifenews.com/2017/04/20/un-says-wo men-who-want-to-avoid-pregnancy-should-use-abortion-as-family-planning/ [dostęp: 25.03.2018].

Globalna koalicja zwalcza wysiłki ONZ zmierzajace do ogłoszenia aborcji „prawem człowieka”, w: Polityka Polska, 23.10.2017, http://politykapolska.eu/2017/10/23/globalna-koalicja-zwalc za-wysilki-onz-zmierzajace-ogloszenia-aborcji-prawem-czlowieka/ [dostęp: 20.02.2018].

Góralczyk B., [Chiny] Koniec chińskiego snu, „Kultura Liberalna” nr 357(45/2015), 12.11.2015, https:// kulturaliberalna.p1/2015/11/12/chiny-goralczyk-wyzwania-demografia [dostęp: 25.03.2018].

Indie - 63 miliony dziewczynek zginęto w wyniku selektywnej aborcji, w: Serwis informacyjny Fundacji „Jeden z nas”, 09.02.2018, https://jedenznas.pl/indie-63-miliony-dziewczynek-zginelowyniku-selektywnej-aborcji/ [dostęp: 25.03.2018].

Komitet praw człowieka o aborcji, w: Federacja na rzecz Kobiet i Planowania Rodziny, 13.11.2017, http://federa.org.pl/komitet-praw-czlowieka-o-aborcji/ [dostęp: 25.02.2018].

Legalnych aborcji w Polsce jest więcej. I to wcale nie z tego powodu, o którym myślicie, w: Gazeta. pl, 01.02.2018, http://wiadomosci.gazeta.pl/wiadomosci/7,114883,22967897,legalnych-aborcji-w-polsce-jest-wiecej-i-to-wcale-nie-z-tego.html [dostęp: 30.03.2018].

Liczba aborcji w Polsce - interpelacja, w: strona internetowa posła Jakuba Kuleszy, 22.09.2016, $<$ https://kulesza.pl/blog/2016/09/22/liczba-aborcji-w-polsce-interpelacja/ [dostęp: 25.01.2018].

Makarewicz J., Kodeks karny z komentarzem, wyd. 3, Lwów, Wydawnictwo Zakładu Narodowego Imienia Ossolińskich, 1932, http://www.wbc.poznan.pl/dlibra/doccontent?id=77578\&dirids=1 [dostęp: 30.01.2018].

Mija 25 lat od uchwalenia tzw. ustawy antyaborcyjnej, w: Gazeta Prawna.pl, 07.01.2018, http:// prawo.gazetaprawna.pl/artykuly/1096129,25-lat-temu-uchwalono-tzw-ustawe-antyaborcyjna. html [dostęp: 25.01.2018]. 
MZ: W 2016 roku w Polsce wykonano ponad tysiac aborcji, w: RMF24, 25.08.2017, http://two jezdrowie.rmf24.pl/aktualnosci/news-mz-w-2016-roku-w-polsce-wykonano-ponad-tysiacaborcji,nId,2432919 [dostęp: 25.01.2018].

ONZ promuje aborcje jako... prawo człowieka, w: Fronda.pl, http://www.fronda.pl/a/onz-promuje -aborcje-jako-prawo-czlowieka,100748.html [dostęp: 25.03.2018].

ONZ twierdzi, że aborcja jest jedna z metod planowania rodziny, w: Serwis informacyjny Fundacji „Jeden z nas”, 21.04.2017, https://jedenznas.pl/onz-twierdzi-ze-aborcja-jedna-metodplanowania-rodziny/ [dostęp: 20.02.2018].

Ordo Iuris odniosto się do uwag Komitetu Praw Człowieka dotyczacych dostępu do aborcji w Polsce, w: www.rp.pl, 30.01.2018, http://www.rp.pl/Zdrowie/301309957-Reakcja-Ordo-Iuris-nauwagi-Komitetu-Praw-Czlowieka-dotyczace-dostepu-do-aborcji-w-Polsce.html [dostęp: 20.02. 2018].

Ordo Iuris: postulaty feministek sq obce dla większości Polek, w: RMF24, 08.03.2017, http:// www.rmf24.pl/fakty/polska/news-ordo-iuris-postulaty-feministek-sa-obce-dla-wiekszoscipolek,nId,2365835 [dostęp: 25.01.2018].

Paweł VI, Encyklika Humanae vitae, w: Opoka.org.pl, 05.07.1999, https://opoka.org.pl/biblioteka /W/WP/pawel_vi/encykliki/humane.html [dostęp: 28.03.2018].

Polska chce usunięcia zapisów w dokumentach ONZ. Chodzi o dostęp do aborcji i karanie kobiet, w: Gazeta.pl, 12.10.2017, http://wiadomosci.gazeta.pl/wiadomosci/7,114871,22506045,polska -chce-usuniecia-zapisow-w-dokumentach-onz-chodzi-o-dostep.html [dostęp: 20.02.2018].

Safe abortion: technical and Policy guidance for health systems, Wyd. 2, WHO, 2012, ISBN 9789241548434, http://apps.who.int/iris/bitstream/handle/10665/70914/9789241548434_eng. pdf? sequence=1 [dostęp: 20.03.2018].

Sprawa Tysiac przeciw Polsce (skarga nr5410_03), wyrok z 20 marca 2007 r. [thumaczenie robocze Ministerstwa Sprawiedliwości], w: Trybunał Konstytucyjny, http://trybunal.gov.pl/polskie-ak centy-w-orzecznictwie-miedzynarodowym/rada-europy-europejski-trybunal-praw-czlowieka/ w-sprawach-polskich/art/7999-sprawa-tysiac-przeciwko-polsce-skarga-nr-5410-03-wyrok-zdnia-20-marca-2007-rtlumaczenie-robo/ [dostęp: 25.01.2018].

US refuses to back UN on abortion access in human rights resolution, „The Guardian” 22.06.2017, https:/www.theguardian.com/world/2017/jun/22/women-abortion-un-human-rights-resolutionus-refuses [dostęp: 25.03.2018].

Wiceszef Msz: ONZ nie powinna angażować się w promowanie aborcji na świecie, w: www.tvp.info, 13.10.2017, https://www.tvp.info/34386990/wiceszef-msz-onz-nie-powinna-angazowac-sie-wpromowanie-aborcji-na-swiecie [dostęp: 20.02.2018].

Yoshihara S., Oas R., Eleven Problems with the 2012 WHO Technical Guidance on Abortion, w: C-Fam, 07.11.2012, https://c-fam.org/wp-content/uploads/11-PROBS-WITH-WHO6.pdf [dostęp: 25.03.2018].

Zięba A., Historia legalizacji aborcji w Europie i w Polsce, w: Sanktuarium św. Józefa w Kaliszu, http://www.swietyjozef.kalisz.pl/OtoczmyTroskaZycie/13.html [dostęp: 25.01.2018].

MiKołAJ GęBKA - dr nauk humanistycznych, socjolog, adiunkt na Wydziale Teologicznym UAM w Poznaniu, absolwent Podyplomowego Studium Rodziny na Wydziale Teologicznym UAM (2003). Autor ok. 20 artykułów. Zajmuje się problematyką rodzinną - praca magisterska (2001) poświęcona młodym małżeństwom, praca doktorska (2008) - społecznej roli ojca. Obecnie zajmuje się problemem dysfunkcji w sferze prokreacyjnej rodziny. 